\title{
MODEL PEMBENTUKAN KELOMPOK BERVARIASI UNTUK MEMBANGKITKAN MOTIVASI BELAJAR SISWA
}

\author{
Sukiman \\ Pendidikan Bahasa Indonesia, Universitas Billfath
}

\begin{tabular}{l}
\hline \hline INFO ARTIKEL \\
\hline Riwayat Artikel: \\
Diterima: 10-11-2018 \\
Disetujui: $15-11-2018$ \\
\\
\hline
\end{tabular}

Kata kunci:

Model

Kelompok Bervariasi

Motivasi Belajar

\author{
Alamat Korespondensi: \\ Sukiman \\ Pendidikan Bahasa Indonesia \\ Program Studi Pendidikan Bahasa Indonesia, Universitas Billfath \\ Komplek PP Al Fattah Siman, Lamongan \\ E-mail: ukitarano@gmail.com
}

Pendidikan merupakan proses mentrasmisikan pengetahuan dari satu orang ke orang lain. Melalui pendidikan diharapkan terbentuknya kedewasaan pada diri anak, baik secara fisik maupun psikis. Menurut Permendiknas Nomor 22 Tahun 2006 tentang Standar isi, kurikulum dikembangkan berdasarkan beberapa prinsip, yaitu relevan dengan kebutuhan kehidupan, pengembangan keterampilan pribadi, keterampilan berpikir, keterampilan sosial (social skill), keterampilan akademik, dan keterampilan vokasional.

Pada Kurikulum 2013 pembelajaran diarahkan pada pemberdayaan semua kompetensi yang dimiliki oleh peserta didik, agar peserta didik memiliki kompetensi yang diharapkan melalui upaya menumbuhkan serta mengembangkan sikap (attitude), pengetahuan (knowledge), dan keterampilan (skill). Kualitas lain pada diri peserta

\begin{abstract}
This study aims to determine the relationship between the information of groups with student motivation. This research was conducted using quantitative methods. While the study design used Pearson correlational roduct moment. Data collection uses documentation techniques and VIII report cacts. Thentation to find student achievement based on grade to learn and the learning model that had been done so far by the teacher. Defense analysis uses SPPS to study motivation using learning motivation. Based on the research conducted, it can be seen that these models have very strong relationships with student motivation. Students feel interested and eager o learn from the beginning have been invited to enjoy learning. After the initial learning has been interested, then naturally the students are excited to learn and follow the lesson.
\end{abstract}

\begin{abstract}
Abstrak: Penelitian ini bertujuan untuk mengetahui hubungan model pembentukan kelompok bervariasi dengan motivasi belajar siswa. Penelitian penakn dengan menggunakan metode kuantitatif. Sementara desain dat mean untuk mengetahui perolehan prestasi siswa melalui nilai raport kelas VIII. Angket dalam penelitian ini digunakan untuk mengetahui motivasi belajar dan model pembelajaran yang dilakukan selama ini oleh guru. Analisis korelasi menggunakan SPPS untuk menguji hubungan motivasi belajar dengan pembentukan kelompok bervariasi dan hubungan keduanya secara simultan tau korela tertarik dan semangat untuk belajar karena dari awal sudah diajak untuk menikmati pembelajaran. Apabila di awal pembelajaran sudah tertarik, maka dengan sendirinya siswa sudah semangat belajar dan mengikuti pelajaran.
\end{abstract}


didik dikembangkan melalui kurikulum dan harus terealiasikan dalam proses pembelajaran, antara lain kreativitas, kemandirian, kerja sama, solidaritas, kepemimpinan, empati, toleransi, dan kecakapan hidup (Hosnan, 2014). Selain itu, dalam Kurikulum 2013 siswa diarahkan untuk memiliki kemampuan berpikir secara kritis. Sementara kekritisan siswa dapat dibangkitkan melalui bermacam model pembelajaran yang diterapkan oleh guru.

Guru bukan hanya dituntut memiliki pengetahuan, keterampilan mengajar dengan kompleksitas peranan sesuai dengan tugas dan fungsi yang diembanya, tetapi juga dituntut untuk kreatif dalam merancang pembelajaran. Hal ini didasarkan bahwa guru menghadapi begitu banyak keunikan dalam kelas, sehingga membutuhkan perancangan yang tepat agar dapat mewadahi semua keunikan siswa.

Proses pembelajaran harus merupakan serangkaian kegiatan yang aktif, menyenangkan dan bermaka bagi siswa. Hal ini didasarkan pada pembelajaran yang bermakna dapat membawa siswa pada pengalam belajar yang sangat mengesankan. Pengalaman yang didapat oleh siswa, akan terasa bermakna apabila proses pembelajaran yang diperoleh merupakan hasil dari pemahaman dan penemuannya sendiri. Penggunaan metode dan media dalam pembelajaran memegang peran yang sangat penting. Sejalan dengan apa yang dikemukakan oleh Hamalik (dalam Arsyad, 2003) pemakaian media pembelajaran dalam proses belajar mengajar dapat membangkitkan keinginan dan minat yang baru, membangkitkan motivasi, dan rangsangan kegiatan belajar, dan bahkan membawa pengaruhpengaruh psikologi terhadap siswa.

Motivasi merupakan syarat mutlak untuk belajar, sekaligus menjadi modal utama bagi terciptanya aktivitas belajar. Hal ini dipahami mengingat bahwa motivasi akan menyebabkan terjadinya suatu perubahan energi yang ada pada diri manusia. Perubahan yang dimaksud, terkait dengan aspek kejiwaan, perasaan dan emosi.

Kurangnya inovasi penunjang pembelajaran merupakan salah satu kendala dalam proses pembelajaran, apabila guru hanya mengandalkan gaya belajar yang bersifat konvensional saja dalam menyampaikan materi, maka suasana pembelajaran kurang menarik bagi siswa. Begitu juga apabila pembelajaran berbasis kelompok dilaksanakan, serta pembentukan kelompok yang monoton tanpa ada variasi, hal tersebut bisa membuat siswa jenuh. Siswa juga merasa kurang aktif dan kurang termotivasi dalam mengikuti pelajaran selanjutnya. Kurangnya motivasi belajar siswa juga berakibat pada kemampuan belajar yang relatif rendah. Hal ini disebabkan oleh proses pembelajaran yang dilakukan oleh guru cendrung bersifat konvensional, baik di tingkat SD, SMP, maupun SMA (Hartana, 2016). Proses komunikasi yang dilakukan oleh guru juga masih kurang oprimal. Berdasarkan observasi yang dilakukan, maka ditemukan siswa masih kurang semangat dalam belajar. Siswa juga sudah dibagi dalam bentuk kelompok-kelompok belajar, sehingga setiap mata pelajaran akan menggunakan kelompok yang sama.

Motivasi belajar merupakan salah satu sub komponen pendidikan yang perlu dikembangkan dalam upaya meningkatkan kualitas pendidikan (Misaroh, 2011). Motivasi sering dikatakan sebagai dorongan yang mengarahkan seseorang pada kegiatan tertentu. Intensitas atau tingkat motivasi dalam diri siswa tidak selalu tetap, melainkan dapat berubah dan dipengaruhi oleh berbagai aspek. Salah satu aspek yang dapat meningkatkan motivasi belajar siswa, yaitu dengan sistem pembentukan kelompok yang bervariasi. Pada saat pembentukan kelompok siswa dibawa untuk bermain agar tertarik dalam pembelajaran. Hal ini sekaligus dapat meningkatkan motivasi belajar siswa yang kurang menjadi lebih semangat.

Motivasi dan belajar merupakan dua hal yang sangat saling mempengaruhi. Belajar lebih mengarah pada terjadinya perubahan tingkah laku secara relatif permanen dan secara pontensial sebagai hasil dari praktik atau penguatan yang dilandasi tujuan, agar tujuan yang diinginkan dapat tercapai secara maksimal. Motivasi yang rendah, menyebabkan siswa tidak semangat dalam belajar, sehingga menghambat pencapaian tujuan pembelajaran.

Motivasi merupakan salah faktor yang sangat penting untuk mendorong semangat belajar siswa (Fauziah, 2017). Di dalam motivasi terdapat keingin dan cita-cita yang ingin dicapai. Dengan demikian, siswa yang memiliki motivasi belajar, akan mengerti dengan apa yang telah menjadi tujuannya dalam belajar, sehingga terjadinya perubahan semangat dan hasil belajar.

Guru sebagai pendidik, harus mampu memperhatikan latar belakang siswa yang bervariasi, sehingga mampu menciptakan metode dan gaya belajar yang dapat menyatukan semua perbedaan latar belakang. Penekanan pada segi kognitif juga masih menjadi hal yang paling dominan diutamakan dalam pembelajaran. Hal ini dapat membuat siswa yang berlatar belakang kurang mampu dalam menangkap materi pembelajaran menjadi tidak semangat. Menurut Dick and Carey (2009:80) karakteristik siswa adalah kondisi-kondisi terketahui yang dimiliki oleh target audience atau target group pada saat siswa mengikuti pembelajaran. 
Guru dalam kelas hanya sebagai fasilitator, yang hanya menyiapkan materi dan merancang pembelajaran agar tujuan yang ingin dicapai terwujud. Senada dengan apa yang diungkap oleh Richard (1998) bahwa peran guru hanya sebagai fasilitator dalam setiap prosses pembelajaran di kelas. Dengan demikian, guru dapat mengurangi metode ceramah yang cendrung mendominasi kelas, sehingga siswa kurang berpartisivasi saat pembelajaraan.

Peranan guru sebagai fasilitator salah satunya adalah memberikan motivasi kepada siswa, sebagaimana diketahui bahwa pemberian motivasi sangat penting untuk menumbuhkan semangat belajar siswa. Pernyataan tersebut sejalan dengan apa yang diungkapkan oleh Purwanto (1990) bahwa dalam belajar, motivasi sangat penting untuk menunjang keberhasilan pembelajaran. Namun, pada suatu sekolah pasti terdapat siswa yang minat dan semangat belajarnya rendah, suka bolos, malas belajar, dan lain sebagainya. Dalam hal tersebut, guru sebagai pendidik sudah gagal memberikan motivasi dan semangat kepada siswa walaupun pada dasarnya sifat malas siswa banyak disebabkan oleh faktor lingkungan. Pada tingkatan SMP siswa belum dapat menumbuhkan motivasi dirinya secara mandiri dan kehadiran orang-orang di sekitarnya diperlukan untuk mendukung semangat belajar (Kurniawan $\&$ Mustqa, 2014).

Salah satu cara yang dapat digunakan oleh guru untuk membangkitkan motivasi belajar siswa dengan merancang pembelajaran secara menarik. Merancang pembelajaran dapat diawali dengan pembentukan kelompok yang bervariasi atau berbeda setiap pertemuan. Dengan demikian, siswa akan tertarik dan termotivasi untuk belajar. Namun, kenyataan yang ada, masih banyak guru yang menggunakan metode pembentukan kelompok yang konvensional atau menggunakan kelompok yang sama pada setiap pertemuannya.

Dengan menggunakan kelompok yang bervariasi, diharapkan terjadi motivasi belajar pada siswa. Menurut Zakaria (2005) pembelajaran kelompok atau kooperatif menciptakan kesempatan yang luas bagi siswa agar terlibat dalam penyelesaian masalah dengan bekerjasama dalam suatu kelompok. Pembelajaran kelompok akan memberikan peluang positif kepada siswa untuk saling ketergantungan dalam mencapai tujuan pembelajaran yang ingin dicapai bersama. Hal ini disebabkan oleh peluang yang dimiliki oleh siswa untuk sukses secara bersama-sama (Sutiman, 2014). Dengan demikian, tujuan penelitian ini adalah untuk mengetahui hubungan model pembentukan kelompok bervariasi dengan motivasi belajar siswa.

\section{METODE}

Metode penelitian yang digunakan dalam penelitian ini adalah metode penelitian kuantitatif. Sementara desain penelitian menggunakan pearson product moment correlational. Variabel yang digunakan adalah variabel bebas dan terikat. Variabel bebas merupakan sebab yang diperkirakan dalam menciptakan terjadinya perubahan pada subjek penelitian. Variabel bebas dalam penelitian ini, yaitu model pembentukan kelompok bervariasi. Variabel terikat merupakan faktor utama yang ingin dijelaskan atau ingin diperinci secara lebih detail. Variabel terikat dalam penelitian ini, yaitu motivasi belajar siswa.

Penelitian ini dilakukan di SMP Simanjaya Sekaran, Kabupaten Lamongan dengan kosentrasi kelas IX R2 dan IX U2. Teknik pengumpulan sampel menggunakan non-probability sampling dengan tipe sampel yang digunakan adalah sampel jenuh. Jumlah sampel dalam penelitian ini sebanyak 55. Pengumpulan data menggunakan teknik dokumentasi dan angket. Dokumentasi digunakan untuk mengetahui perolehan prestasi siswa melalui nilai raport kelas VIII. Angket dalam penelitian ini digunakan untuk mengetahui motivasi belajar dan model pembelajaran yang dilakukan selama ini oleh guru.

Analisis korelasi menggunakan SPPS digunakan untuk menguji hubungan motivasi belajar dengan pembentukan kelompok bervariasi dan hubungan keduanya secara simultan terhadap motivasi belajar. Data yang diperoleh memlalui angket motivasi belajar dan model pembelajaran akan diolah dengan menggunakan skala likert dengan respon atas pernyataan, yaitu skor 1 sampai dengan 4. Berikut tabel yang digunakan sebagai instrumen dalam penelitian ini. 
Tabel 1. Instrumen Penelitian

\begin{tabular}{|c|c|c|c|c|c|}
\hline Variabel & Data & $\begin{array}{c}\text { Teknik } \\
\text { Pengumpul } \\
\text { an Data } \\
\end{array}$ & Instrumen & Sasaran & Indokator \\
\hline $\begin{array}{l}\text { Pembentukan } \\
\text { Kelompok } \\
\text { Bervariasi }\end{array}$ & $\begin{array}{l}\text { Skor } \\
\text { Pembentukan } \\
\text { Kelompok } \\
\text { Bervariasi }\end{array}$ & Angket & $\begin{array}{l}\text { Angket } \\
\text { Pembentukan } \\
\text { Kelompok } \\
\text { Bervariasi }\end{array}$ & Siswa & $\begin{array}{l}\text { 1. Manfaat pembentukan kelompok } \\
\text { 2. Model pembentukan kelompok } \\
\text { 3. Ragam pengunaan kelompok } \\
\text { 4. Kemenarikan dalam } \\
\text { pembentukan kelompok }\end{array}$ \\
\hline $\begin{array}{l}\text { Motivasi } \\
\text { Belajar }\end{array}$ & $\begin{array}{l}\text { Skor Motivasi } \\
\text { Belajar Siswa }\end{array}$ & Angket & $\begin{array}{l}\text { Angket } \\
\text { Motivasi } \\
\text { Belajar Siswa }\end{array}$ & Siswa & $\begin{array}{l}\text { 1. Perhatian } \\
\text { 2. Ketertarikan } \\
\text { 3. Kepuasan } \\
\text { 4. Rasa percaya diri }\end{array}$ \\
\hline
\end{tabular}

\section{HASIL}

Berdasarkan hasil uji korelasi yang dilakukan dengan menggunakan SPSS terhadap pembentukan kelompok bervariasi dan motivasi belajar siswa dapat dilihat pada tabel 2 di bawah ini.

Tabel 2. Analisis Korelasi antara Pembentukan Kelompok Bervariasi dengan Motivasi Belajar

\section{Correlations}

\begin{tabular}{llrr}
\hline & Kelompok Bervariasi & Motivasi Belajar \\
\hline Kelompok Bervariasi & Pearson Correlation & 1 & $.520^{* *}$ \\
& Sig. (2-tailed) & & .003 \\
& $\mathrm{~N}$ & 31 & 31 \\
\hline Motivasi Belajar & Pearson Correlation & $.520^{* *}$ & 1 \\
& Sig. (2-tailed) & .003 & 31 \\
& $\mathrm{~N}$ & & 31 \\
\hline **. Correlation is significant at the 0.01 level (2-tailed).
\end{tabular}

Berdasarkan tabel di atas dapat diketahui bahwa antara pembentukan kelompok bervariasi dengan motivasi belajar memiliki korelasi yang signifikan. Nilai Pearson's r sebesar 0, 520 dengan Sig.(2-tailed) 0,003 atau lebih kecil dari 0,05. Data tersebut menunjukkan bahwa kedua variabel memiliki hubungan yang sangat nyata.

Hasil angket yang diberikan kepada siswa berkaitan dengan model pembentukan kelompok bervariasi yang digunakan oleh guru juga menunjukkan hasil yang sangat bagus. Hasil angket yang diberikan kepada siswa dapat dilihat pada tabel di bawah ini. 
KARANGAN: Jurnal Kependidikan, Pembelajaran, dan Pengembangan, Vol 01, No 01, Bln Feb, Tahun 2019, Hal 1-7

Tabel 3. Penggunaan Model Pembentukan Kelompok Bervariasi

\begin{tabular}{llccl}
\hline No & \multicolumn{1}{c}{ Indikator } & \% & NA \% & Keterangan \\
\hline 1. & $\begin{array}{l}\text { Manfaat pembentukan kelompok bagi } \\
\text { siswa }\end{array}$ & $80 \%$ & $80 \%$ & Sangat Bermanfaat \\
\hline 2. & $\begin{array}{l}\text { Model pembentukan kelompok yang } \\
\text { digunakan oleh guru }\end{array}$ & $80 \%$ & $75 \%$ & Model yang digunakan sudah cukup \\
\hline 3. & $\begin{array}{l}\text { Ragam penggunaan kelompok yang } \\
\text { digunakan dalam pembelajaran }\end{array}$ & $50 \%$ & $50 \%$ & Ragam model yang digunakan kurang \\
\hline 4. & $\begin{array}{l}\text { Kemenarikan dan kebermaknaan } \\
\text { pembentukan kelompok yang digunakan }\end{array}$ & $80 \%$ & $80 \%$ & $\begin{array}{l}\text { Pembentukan kelompok yang digunakan sangat } \\
\text { menarik dan bermakna }\end{array}$ \\
\hline
\end{tabular}

Berdasarkan tabel 3 di atas, dapat diketahui bahwa penggunaan model pembentukan kelompok bervariasi sangat bermanfaat bagi siswa. Hal ini dapat dilihat dari persentase tanggapan siswa, yaitu sebesar $80 \%$. Di mana persentase tersebut dapat dikategorikan sebagai standar keberhasilan dalam membuat pembagian kelompok menjadi lebih bermanfaat. Model pembentukan kelompok yang digunakan oleh guru sudah dapat dikatakan cukup, apabila dilihat dari persentase yang ada, yaitu 75\% siswa memberikan tanggapan cukup terhadap model pembentukan kelompok yang disiapkan Ragam penggunaan kelompok yang digunakan dalam pembelajaran masih dikategorikan. Hal ini didasari oleh hasil persentase tanggapan siswa sebesar 50\%. Dari segi kemenarikan dan kebermaknaan pembentukan kelompok yang digunakan sudah sangat menarik bagi siswa, yaitu $80 \%$.

Model pembentukan kelompok yang digunakan oleh guru ada tiga, yaitu guru menggunakan kartu warnawarni, amplop kejutan, dan makanan favorit. Ketiga model tersebut digunakan pada setiap pertemuan yang berbeda. Setiap pertemuan menggunakan model pembentukan kelompok yang berbeda dan anggota kelompok diusahakan untuk berbeda setiap pertemuannya. Ragam kelompok yang digunakan masih bersifat monoton, di mana kelompok masih berbentuk lingkaran.

Pertama, Pembagian kelompok dengan menggunakan kartu warna-warni dilakukan pada pertemuan kedua setelah pretest dilaksanakan. Adapun langkah-langkah pembentukan kelompok menggunakan kartu warna-warni sebagai berikut: (1) guru menyiapkan enam lembar kertas bupalo dengan warna yang berbeda-beda; (2) kertas dipotong membentuk kartu sebanyak jumlah anggota kelompok; (3) kartu yang sudah dipotong kemudian diselipkan di balik hasil pretest siswa; dan (3) pada hitungan ketiga, guru meminta siswa untuk berkumpul sesuai dengan warna yang telah ditentukan. Pemberian nama kelompok didasarkan pada warna yang diperoleh oleh masing-masing kelompok. Pembagian kelompok dengan kartu warna-warni dapat menyatukan siswa dengan berbagai tingkatan pengetahuan.

Kedua, pengunaan amplop kejutan dalam pembentukan kelompok dapat dilakukan dengan cara: (1) guru membuat nama siswa beserta nama kelompok, kemudian dimasukan dalam amplop; (2) masing-masing siswa diminta mau ke depan sesuai dengan nomor absensnya untuk menerima amplop dari guru; (3) pada hitungan ketiga guru akan meminta siswa untuk membuka amplop secara bersama-sama; (4) siswa yang mendapatkan nama kelompok sama, maka akan menjadi satu tim. .Ketiga, pembagian kelompok dengan makanan favorit dilakukan dengan cara: (1) guru menyediakan enam macam jenis makan; (2) guru meminta siswa untuk memilih satu dari enam jenis makanan yang sudah terterah dilembaran; (3) siswa yang memilih makanan sama, maka akan menjadi tim; dan (4) guru meminta siswa untuk membuat yel-yel berdasarkan makanan pilihannya.

Kelebihan penggunaan kelompok bervariasi, yaitu: (1) siswa merasa lebih senang dalam pembelajaran, karena pada bagian pembuka pembelajaran sudah diajak untuk bermain dan menikmati pembelajaran, (2) siswa bisa merasakan berbagai macam bentuk pembagian kelompok, sehingga tidak merasa jenuh dan bosan, (3) siswa pada setiap pembagian kelompok bisa lebih saling mengenal, karena setiap pembentukan kelompok selalu berbeda anggota, dan (4) siswa lebih percaya diri dan bertanggungjawab karena dilibatkan secara penuh dalam pembagian kelompok dan kelompok. Namun, dibalik kelebihan dari penggunaan kelompok bervariasi ada beberapa kekurangan yang perlu diketahui, yaitu: (1) guru membutuhkan waktu yang cukup lama untuk merancang pembentukan kelompok, (2) guru harus lebih kreatif dalam memilih model atau cara pembagian kelompok, (3) membutuhkan banyak persiapan, (4) membutuhkan banyak bahan dan alat yang harus disiapkan agar setiap pembagian kelompok tidak terjadi kesamaan, dan (5) membutuhkan sedikit dana untuk menyiapkan bahan-bahan yang diperlukan. 
Dalam penggunaan pembagian kelompok bervariasi guru dituntut untuk aktif dan kreatif, sehingga dapat menghasilkan gaya pembagian kelompok yang berbeda-beda. Pembagian kelompok yang berbeda dapat membangkitkan semangat belajar siswa. Hal ini disebabkan oleh suasana pembelajaran yang dibawa dalam keadaan yang lebih santai dan nyaman. Siswa diajak untuk menikmati pembelajaran melalui pembagian kelompok. Siswa juga dilibatkan secara penuh dalam pembelajaran dan tidak ada perlakukan khusus pada salah satu siswa, karena siswa diperlakukan secara sama.

\section{PEMBAHASAN}

Berdasarkan hasil analisis pada tujuan yang ingin dicapai pada penelitian ini, yaitu melihat korelasi antara model pembentukan kelompok bervariasi dengan motivasi belajar siswa. Hasil penelitian yang telah dilakukan dapat dilihat bahwa ada korelasi yang kuat sekali antara kedua variabel. Indikator yang digunakan untuk mengidentifikasi tingkat motivasi belajar siswa, yaitu; perhatian siswa, ketertarikan siswa, kepuasaan siswa, dan rasa percaya diri siswa. Keempat indikator tersebut kemudian dijadikan acuan dalam melihat sejauh mana tingkat motivasi belajar siswa dengan menggunakan model pembentukan kelompok bervariasi yang dilakukan oleh guru.

Dari hasil analisis yang dilakukan, maka penggunaan model pembentukan kelompok yang bervariasi memiliki hubungan kuat dengan tingkat motivasi belajar siswa, yaitu 0,520. Hal ini sejalan dengan apa yang dikatakan oleh Syarif (2002); Ulandari (2014) bahwa motivasi belajar sangat ditentukan oleh keterampilan guru dalam menggunakan berbagai macam variasi pembelajaran, terutama ketika pembentukan kelompok. Penggunaan model pembelajaran, khususnya teknik pembentukan kelompok yang dilakukan oleh guru sangat membantu siswa dalam belajar. Teknik pembentukan kelompok dapat dilakukan dengan cara yang berbeda setiap harinya. Dengan demikian, motivasi belajar akan meningkat, karena mengalami hal yang berbeda setiap harinya.

Indikator yang digunakan untuk melihat adanya hubungan antara model pembentukan kelompok bervariasi dengan motivasi belajar, yaitu: (1) kebermanfaatan model yang digunakan; (2) jumlah model pembentukan kelompok yang digunakan; (3) ragam bentuk kelompok; dan (4) menarikan dalam pembentukan kelompok. Berdasarkan angket yang disebarkan kepada siswa, maka dapat diketahui persentase tanggapan siswa terhadap model pembentukan kelompok yang digunakan sudah mencapai rata-rata, yaitu 80\% kecuali ragam pembentukan kelompok yang masih di bawah rata-rata. Hal didasari dengan luas ruang kelas yang tidak memungkinkan untuk mengadakan model kelompok selain lingkaran.

\section{SIMPULAN}

Berdasarkan pada hasil penelitian dan pembahasan, maka dapat diketahui bahwa model pembentukan kelompok bervariasi memiliki hubungan atau korelasi yang kuat sekali terhadap motivasi belajar siswa. Siswa merasa tertarik dan semangat untuk belajar karena dari awal sudah diajak untuk menikmati pembelajaran. Apabila di awal pembelajaran sudah tertarik, maka dengan sendirinya siswa sudah semangat belajar dan mengikuti pelajaran. Di mana, awal atau pembuka pelajaran menjadi bagian yang sangat penting untuk berhasil tidak materi pembelajaran tersampaikan.

\section{DAFTAR RUJUKAN}

Amni, Fauziah. 2017. Hubungan Antara Motivasi Belajar dengan Minat Belajar Siswa Kelas IV SDN Poris Gaga 05 KotaTangerang.

Azhar, Arsyad. 2003. Media Pembelajaran. Jakarta: Raja Grafindo Persada.

Depdiknas. 2006. Permendiknas Nomor 22 Tahun 2006 tentang Standar Isi Kurikulum. Jakarta: Kemendikbud.

Dick, W and Carrey, L. 1985. The Systematic Design Instruction. Secon edition. Glenview.

Illinois: Scott., Foreman and Company

Effandi Zakaria and Zanaton Iksan. 2007. "Promoting Cooperative Learning In Science and Mathematics Education: a Malaysian Perspective" Eurasia Journal Of Mathematics, Sciens \& Technologi, (3(1), 35-39

Hosnan, M. 2014. Pendekatan Saintifik dan Kontekstual dalam Pembelajaran Abad 21. Jakarta: Ghalia Indonesia. 
KARANGAN: Jurnal Kependidikan, Pembelajaran, dan Pengembangan, Vol 01, No 01, Bln Feb, Thn 2019, Hal 1-7

Kurniawan, D., \& Wustqa, D. U. 2014. Pengaruh Perhatian Orangtua, Motivasi Belajar, dan Lingkungan Sosial terhadap Prestasi Belajar Matematika Siswa SMP. Jurnal Riset Pendidikan Matematika, 2(1), 176-187.

Purwanto, Ngalim, 1990. Psikologi Pendidikan. Bandung: Rosdakarya.

Richard, Arend I. 1998. "Pembelajaran Cooperative" dalam buku Clasroom Instruksional and Management. Tim Restrukturisasi Kurikulum PBM IKIP Surabaya.

Sumanto. 2014. Psikologi Pendidikan. Jakarta: Rineka Cipta.

Sutiman, Antuni Wiyarsi, Erfan priyambolo, 2014. Efektivitas Pembelajaran Kooperatif dalam Meningkatkan Aktivitas dan Motivasi Belajar Mahasiswa Pada Perkuliahan Filsafat Ilmu. Jurnal Pendidikan Matematikan dan Sains Tahyn II, no. 1, Juni 2014.

Syarif, I. 2002. Pengaruh Model Blended Learning terhadap Motivasi dan Prestasi Belajar Siswa SMK. Jurnal Pendidikan Vokasi, 2(2), 84-94.

Ulandari, K. S. S. 2014. Hubungan Antara Motivasi Belajar dengan Prestasi Belajar Siswa SD Kelas V Semester Ganjil di Desa Buruan. Jurnal Mimbar PGSD Universitas Pendidikan Ganesha, 1(2). 